\title{
Branding strategies for service firms- a study on the selected Internet Service Providers (ISPs) in Bangladesh
}

\author{
Abdul Hamid Chowdhury ${ }^{1}$, Md Shahnur Azad Chowdhury ${ }^{2}$, Mohammad Imran ${ }^{3}$ \\ ${ }^{1}$ Associate Professor, Department of Business Administration, International Islamic University Chittagong, BANGLADESH \\ ${ }^{2}$ Assistant Professor, Department of Business Administration, International Islamic University Chittagong, BANGLADESH \\ ${ }^{3}$ Lecturer, Department of Business Administration, USTC, Chittagong, BANGLADESH
}

\begin{abstract}
Research work has been done on how to create a brand supporting behaviour but most of the time the existing insights have generally stemmed from research with management, brand practitioner's and even consumers' perspectives. Very little has been done to research the employees' perception towards internal branding and to compare the view of the management and employees' on internal communication. The existing researches are also done on mostly in the context of the businesses in industrialize countries whereas this research would be an intent to find the internal branding practice in a service firm in a country of developing economy. This would able to identify the gap in the practice of internal branding in different socio-economical context. This research is dedicated to find out both back end and front end skilled employees' view towards internal communication in a service firm and based on the findings attempt would be done to see whether the staffs perceive their role differently towards the brand. For conducting the research qualitative data were gathered from the qualitative survey by questioning different employee and management about the internal brand communication and the analysis was done on that. With the respondents view on the internal marketing process, the management do not have fully structured plan to implement a sound internal branding strategy. With a given economical constraint it is not always possible to practice all the aspect of management science, but from the study of the company we can see that service firms such as ISP (internet service provider) companies in weaker economical countries could increase the internal communication practice by just altering the existing inter-departmental communication monitored by innovative senior management, coordination of HRM and Marketing with input from engineers.
\end{abstract}

Keywords: Branding, Strategy, Internal Marketing, ISP

\section{INTRODUCTION}

$\mathrm{B}_{\mathrm{o}}^{\mathrm{r}}$ randing is one of the important strategic components of business. The branding procedures can be handled by a specific department dedicated to it. Also, there are companies that get these jobs done by transforming the brand activities to the corporate culture of the company and the management work for making the brand a success. A holistic brand image integrates entities such as values, colours, name, symbols, words and slogans. Berr et al (1988) argued that once an organisation establishes a favourable brand image, its main task is to ensure consistency.

They further argued that since service companies often follow a monolithic branding strategy, consumers mentally group the entire corporation's portfolio together expecting uniformity; thus management of brand consistency is even more important. "Amber and Styles (1996, p10) define brand as the promise of bundle of attributes that someone buys.... The attribute that make up a brand may be real or illusory, rational or emotional, tangible or invisible" (De Chernatony and Segal-Horn, 2003, pp.1098).For services firm, the attribute of the brand is not tangible but visible by the consumers. What sort of service they get and what sort of customer care the company offers for their customers are all visible in modern days where service firms got their offices in the high streets with people

working for customer care. Also, another addition is the website of the company and call centres. Customers get impression about the service firm by experiencing their website functionality and customer care call centres.

To deliver the brand message to the employees and to make them work for achieving the brand promise, it is very important to teach the brand to them. The equity of the brand is initially estimated from the consumers' perception towards such companies in same business but as the business grow bigger the need for an own branding strategy emerges to increase the brand equity. Internal branding is the base for the brand strategists. "Internal branding is considered as a means to create powerful corporate brands. It functions as a link between communication, service and quality"(Punjaisri and Wilson,2007,p.60).

\section{Objectives of the Study}

The research is concentrated on the internal activities of the company that lead the way to get the brand identity and to investigate it according to the existing literature.

Three main research questions are set:

- To investigate internal marketing tools and techniques used in an ISP in Bangladesh and what the employees view on it;

- To investigate which management department or 
group of employees should be better targeted for internal marketing;

- To investigate the relationship between brand identity created by internal marketing and external marketing;

\section{Methodology}

Qualitative data were gathered from the qualitative survey by questioning different employee and management about the internal brand communication and the analysis was done on that. The research process by Howard and Sharp (1983) was followed for this research. For the study of internal marketing practice and its impact on ISPs workers, employees in various front end and back end skilled workers were chosen. This is to gather their views on various attributes of internal marketing that prevails in the existing management. A sample was chosen that constitutes of few front end and few back end staffs. Front end people were chosen who generally sell the brand to the customers' i.e who takes part in the marketing communication part directly whereas the back end staffs were chosen who normally observe the marketing communication activities but do not take part on it directly. This was done to gather data about internal branding procedure in the firm from different point of view. Those who sell the brand outside might live the brand differently than the people who work for the service quality in an ISP (Internet Service Provider) but not necessarily take part in the marketing communication brand. So, the effect of internal branding could be different between two groups of employees.

\section{Branding}

According to American Marketing Association a brand is "a name, term, sign, symbol, or design, or a combination of them, intended to identify the goods or services of one seller or group of sellers and to differentiate them from those of competitors." (Keller, 2003, p.3) .There are tasks associated with selecting a specific name or logo for a service or product organization. The strategy makers of companies need to spend lot of time thinking and deciding about the proper strategy to use the brand as the company's competitive advantage over its competitors. Doing this, need an attempt to inline the Human Resource Department, Marketing Department, Corporate identity or culture, Executive member's thinking and moreover the employees' perception of the organization by understanding their roles in the business.

\subsection{BRANDING STRATEGY}

Brand management is essential for a sound branding strategy for organisation. "The strategic brand management process involves the design and implementation of marketing programs and activities to build measure and manage brand equity. The strategic brand management process is defined as involving four major steps:
- Identifying and establishing brand positioning and values;

- Planning and implementing brand marketing programs;

- Measuring and interpreting brand performance;

- Growing and sustaining brand equity." (Keller, 2003,p44)

\subsection{BRAND IDENTITY}

Brand is a name given to a product or service so a consumer can recognize it amongst other products or services on the market. Also, for its unique identity brand name requires its other attributes such as logo, colour or goodwill in the market. "Building the brand identity requires additional decisions on the brand's name, logo, colours, tagline, and symbol" (Kotler,2003, p.420) .At the same time, a brand is much more than a name, logo .colours or symbol. A brand should be identified according to the promise of product and service to the customers and how much does it really fulfil.

\subsection{BRAND EQUITY}

Brand equity is to enhance the brand identity with the process of studying the brand from different perspectives by analysing its position in the market and consumer behaviour. "Brand equity is the added value endowed to products and services. This value may be reflected in how consumers think, feel and act with respect to the brand, as well as the prices, market share, and profitability that the brand commands for the firm."(Kotler \& Keller, 2006, p276).

\subsection{INTERNAL MARKETING IN MANAGEMENT}

The value that exists within the organization and consumers towards its brand is to be identified and then measures could be taken to sustain it. "Unless values can be effectively identified and then selectively sustained, the brand is likely to lose its way amongst both customers and employees" (De Chernatony, Drury \& Horn, 2004, p74). For services organisation, employee or internal customers play a vital role for shaping its brand value to the customers because they are the people customers' first approach when they come in touch with the brand. It is different to product branding, where customer know about the product from packaging, advertisement and other marketing communications. The employees in a service industry need to act according to the stake-holder's expectation. To perform this, service organisation staffs should be trained according to recent change in society. The value of the organisation can be altered according to changes in society. "The objective of internal branding is to ensure that employees transform espoused brand messages to brand reality for customers and other stake-holders" (Punjari and Wilson, 2007, p.60). The internal branding of the company according to the stake-holder's expectation and change in society is needed. In this way, organisation and 
its employees know which value to sustain.

A service culture with the customer can be achieved by constantly pursuing four areas below:

1. Viewing employees as internal customers:

2. Meeting service standard expectations:

3. Training and development:

4. Offering employees incentives:

\subsection{INTERNAL MARKETING TO INTERNAL BRANDING}

In this section, more detail will be drawn on how to turn the existing internal communication into internal branding. Measuring the brand from the employees' perspective can help create successful branding strategy. Successful companies could have internal communication between employees and departments to reach the service goal but all these internal marketing are not always the internal branding. Internal branding needs more systematic approach to measure and sustain the brand identity by the mean of improving the whole system of internal communication. Internal marketing influence in these management processes by helping in transforming the brand value to the workers.

\subsection{INTERNAL BRANDING BY LEADERS AND CORPORATE CULTURE}

In service firms where brand management is not done on a professional manner still holds some value on its organization. These values are mostly emergent in nature. "For a services brand, the values tend to be of a more emergent nature that is more dependent upon a company's founder (Ciulla, 1999; Davidson, 2002) and its employees" (De Chernatony \& Segal-Horn, 2004, p77). There are set codes of conduct for the employees for their input according to the business scenario but most of the time workers tend not to abide by all the codes of conduct whereas those codes are formulated with the assumption that all those would be necessary to sustain the brand value.

\subsection{INTERNAL BRANDING BY ORGANISATIONAL PERFORMANCE}

The value should be shared amongst all employees that create better understanding of the job they are doing and give them the idea of how much is expected from them. The managers should play a vital role in it by creating the commitment, internal loyalty and clearer brand understanding amongst service organisation employees. "Many writers regard the "service encounter" the moment of interaction between the customer and the firm (Lovelock, 1988) also known as the moment of truth."(De Chernatony \& Segal-Horn,2003,p.1096).So, a person answering customers query on the phone should know about the brand value along with his/her skill in handling customer queries. The differentiation with other companies in these matters could be certain way of welcoming, fast response or method of answering customer queries.

Copyright (C) 2013, Asian Business Consortium | ABR
4.8 THE COMBINATION OF MARKETING AND HRM DEPART-

\section{MENT}

As marketing department is always the department of the organization which love to do things independently, the involvement of HRM in marketing activities could be concern to the marketing people. They might not like the idea of different department people intervening in their territory, trying to give them advice on how things could be done. These facts could be well handled by a strong leader who could be the CEO of the organization who has got ample sound knowledge about the work processes. By internal and external marketing, the brand equity increases with the input from both HRM and marketing department. It is more like a total quality management situation where every activity inside and outside organization are circled around increasing brand value. "Aurand et al. present a call for us to get on with improving internal marketing and, in doing so, to get out of our traditional functional positions and develop strategies that marry the complementary skills of HR professionals and marketers" (W. Aurand, Gorchels \& R.Bishop,2005).The internal marketing is mainly could be done by the HRM personnel and external marketing of the brand is purely the marketing peoples job. They can contribute to each others work because better organizational culture delivers better service which could be used inline with any advertising campaign.

\subsection{INTERNAL BRANDING BY TRAINING}

Training programs could be undertaken by management to guide the employees to deliver service according to the brand value. But, it is argued by brand writers that only training to the employees is not enough to motivate employees. Rather, there are more ways of internal branding that could influence staffs better. One of the convenient ways is motivating the staffs through mass media campaigns. "Continuous brand success can be improved if the brand promise that is communicated through a company's mass media campaigns is lived up to by each of its employees" (Henkel et al,2007,pp.310-320).Adopting private branding strategy can contribute to better internal marketing communication and it can draw the attention of external customers towards the brand. i.e if customer approach a internet service provider for internet connection the professionalism of the person on the phone could connect that person to the company. Also, when they come to know that, the same ISP(Internet Service provider) got calling card on the market or owns the biggest cyber café on the city center could give them better impression about the brand. This also gives the front desk staffs options to talk about. They can use these as the brand's identity when they are approaching a new customer. For the corporate customers, the company's association with the other big companies by providing them with Network infrastructure, making their website can be used as marketing tools. In this way an ISP business could be well explained 
to the employees and the way to explore the business to the new customers opens to them. (Herstein and Gamliel, 2006).

\section{Data Analysis and Findings}

This chapter intends to reveal in what extent internal branding is practised for the brand of ISPs by gathering and analysis all the qualitative data from the survey on the internal marketing of the firms. The responses are gathered from self administered questions. "Self administered questionnaires are better at generating information from highly structured questions"(Burton, p.322).A research through mail or telephone surveys tends to be more cost effective than personal interviews which are more labour intensive but overall response rates are frequently better with face-to face interviews. The researcher and the case study company being in distant places made it even costlier for the researcher to conduct face-to-face interview or telephone interview. Though attempts were given to collect data through instant messenger service software which allow voice data as well but due to extreme busy environment of the firms everyone was reluctant to sit for the interviews. Senior executive engineer, Assistant marketing manager, Manager Customer Relations, customer care division, AMM- marketing and sales, executive-marketing and sales, Assistant manageraccounts view on different aspects of internal branding literature are gathered through email response to qualitative questionnaires. All the interviewees were male of an age range 26-32. Only two respondents were above 30.

The qualitative researcher analyses the interviews by coding text whether that be sentences or phrases, and uses the quotations to prove or disprove various theoretical propositions. "The simplest type of questions generates a dichotomous response which admits only the answers yes or no with additional spaces for Don't know" (Burton, p.338).

On the qualitative survey, 17 qualitative questions were asked to examine their view on their introduction of the company .Question 1-4 was designed to reveal what sort of communication are done with them in their introduction to the company. Question 5-9 was planned to get the view of the employees on the influence of the external marketing communication of the company in the internal marketing activities. Question 10-17 was designed to get the employees view on the management responsible for the internal communication and how it could ensure much effective internal communication for selling the brand to the employees.

\subsection{INTRODUCTION TO THE FIRM'S BRAND}

Introduction to the brand is the most important part in formulating branding strategies. When questions are asked about how they get introduced to the firms brand and which department does this job, three of the respond- ents said they were introduced to the business environment by the department they work for. One respondent mentioned about orientation lecture but has not mentioned about which department does the orientation. Different answers were gained from one front end and one back end skilled staffs. One engineer said new employees are introduced by the customer relation management whereas the customer relation manager mentioned that new employees are introduced to the company and its brand by the Chief Executive Officer himself.

"First through organogram chart then physically as it is very cautiously done by our CEO. Then the new one is to introduce with our website www.colbd.com by our HR representative... it helps to know about the company and its products and various features"

When looked at the ISPs website, it was found that firms website use their monogram along with other statements like "the best ISP with E1 Switch" Or "The ISP has already obtained its brand name recognition for fastest broadband internet services in the city "on their website, which is reasonable if the new employee is later shown how do they perform their duties to turn those statements to reality and what the brand name means to the employees. But, those introduction processes mentioned by different respondents give an impression that no dedicated department actually introduce the new employee to the brand. Also, according to the Plano gram, there is no post for the HR. most of the human resource job is dealt with CEO with co-ordination of the related departments. Successful brand is additional decisions about the brand (Kotler, 2003) which requires growing the brand equity inside the organization which add value to the service of the firm. This requires study of how the management could be designed better to deliver the internal marketing to the employees. This matter was reflected better from the respondents view on the internal marketing that exists in the companies.

\subsection{MARKETING COMMUNICATION}

Marketing communication can give all the employees in the business a direction in which way the organization is heading and also it helps HRM and senior management to sell the brand to the employees by referring to the communication in the market. The customer base and relationship with the supplier of networking machineries could be referred to in case of selling the brand to the employees of the firms. When asked if the marketing communication of the company is informed to them in advance, they all agreed that the company informs them but Assistant marketing manager said "Marketing related employees get the information in advance" which is sensible. They should know about it earlier. For successful branding strategy formulation it is also equally important letting other employees know about marketing communication like sponsoring musical concert or putting an advert on the national television, which at this moment the firm 
does. When they were asked if informing about the brand motivate them better to deliver better service, all of them except marketing and sales executive disagreed. The marketing people in many cases do not want to share their activities to other departments which are drawn on the literature review as well. This view is a reflection of that point. Service management practice requires being an interest to much broader audience than the department responsible for it which could be done by marketing and operations relationship (De Chernatony \& Segal-Horn, 2003). As he is a marketing person himself who has to sell the brand anyway, he does not find it important to be informed about the existing communication. Also, successful internal marketing requires information sharing amongst different departments and he personally might not like sharing the external marketing activities to other department staffs as this is a extra job for him. Another factor could have influenced him for having such a view which is that he is the one who has got only 2 months of working experience with the firm. Even though the firm does inform about its marketing communication to the employees, may be the new employees take some time to perceive the brand identity. The staffs might need some time to compare the external marketing communication to the internal practice and as long as they see significant gap between what is promised outside and what is practised inside the organisation is significant they do not get motivated.

Mixed replies came when the interviewees were asked to describe the existing marketing communication though all of them somehow agreed that successful marketing communication of the company motivates them better and gives positive changes in their performance. Customer relation and marketing executives mentioned about different forms of marketing communication including field level support and marketing. A marketing executive described it as:

"I always try to deliver information to the customer. Because the firm only can provide update service in Chittagong. For good service, COL is the best"

\subsection{MANAGEMENT OF INTERNAL BRANDING}

The researcher looked at the internal communication activities to examine how much of it is could be termed as internal branding practice or it is just the necessary communication for getting short term profitability. Attempt was given to find which department is responsible for the internal marketing and what the staffs saying about the responsible departments. When it was asked to mention which department of management is important for internal communication among the management and staffs, mixed responses came as three respondents mentioned senior management, two of them mentioned HRM .One marketing executive thinks marketing department of the firms is playing important role for internal communica-

Copyright $(C 2013$, Asian Business Consortium | ABR tion. The engineer thinks HRM, Marketing and the senior management in combine are important for delivering the internal communication.

When asked about other departments contribution according to the internal marketing everyone seem satisfied with other departments contribution but one engineer urges for better inter department communication. He mentioned:

"Every department of a company should have the clear and transparent internal communication between them and themselves".

Sales executive and the accountant mentioned that sometime the engineers are careless about such communication. They sometime do not supply necessary information to other departments when it is needed.

\section{How to Improve the INTERnAL MARKeting Process?}

Different replies found from different staffs when suggestions were invited from them to improve the internal marketing process to sell the brand better to the employees. Most of the staffs mentioned about increasing interdepartment communication, more frequent meetings (at least once a week) for better internal marketing of the firms brand. One very important suggestion came from the senior executive engineer who has been serving the company for 5 years and who is the senior person in the company (age 33):

"Every employee should have to respect to others position; job responsibilities should be well defined and should have an organizational hierarchy followed by the employee strictly"

He also mentioned about more frequent functions, meeting, and get-together for the success of the internal marketing. As a most experienced and back end engineering staff this is a well mentioned comment about the management and the inter-departmental communication. The word 'respect' specifies that, a lot to be looked at to determine the relationship between front end and back end staff in a service organization. Another front end sales executive who has been serving the company for two months only gave the most specific answer where he said:

"Only trained management person can improve the internal communication"

This gives us another impression that though the internal communication procedures exist which emerges from the responses of the earlier questions, the management responsible could deliver it better. These suggestions are worth taking into consideration for delivering internal communication better. ISPs are into a quite new market segment where the industry is just growing in one of the developing country of the world. Also, it is more like an 
entrepreneur firm where the CEO, who is only 28 years old, started the business in 2003 by realizing the niche in the market for similar business in Chittagong. Taking these factors into account, and by analysing the respondents' replies, the brand of the firms have been marketed to the employees which could even well marketed by enhancing the ability of the management to deliver internal communication that will lead them to achieve the brand vision which is "Speed without compromise". The finance involve in the enhancement is worth by considering the performance boost it can give to the employees which will give much profitability.

\section{Conclusions}

The study reveals insights of internal branding and its implication on the management practice. These implications are compared to a case study service company in an economical context where such businesses are just emerging with the given economical barrier. What emerges is that though there are internal marketing activities to sell the brand to the employees, there is no structured approach to turn every internal communication activities to internal branding which could increase the brand identity to the employees. This in turn could result in better consumer perception to the ISP firm brand as they get better service from the staffs. These can contribute to enrich the brand equity which could be used for introductory speeches to the new employees and in marketing communications.

\section{REFERENCES}

Ambler, T. and Styles, C. (1996), "Brand development versus new product development: towards a process model of extension decisions", Marketing Intelligence \& Planning, Vol. 14 No. 7, pp. 10-19

Aurand,TW;Gorchels, L and Bishop, TR(2005) 'Human resource management's role in internal branding', Journal of Product $\mathcal{E}$ Brand Management, Volume $14 \cdot$ Number 3 $2005 \cdot$ pp.163-169

Backhaus ,K and Tikoo,S (2004), 'Conceptualizing and researching employer branding', Career Development International, Vol. 9 No. 5, pp. 501-517

Balmer, J.M.T. and Wilkinson, A. (1991), “Building societies: change, strategy and corporate identity", Journal of General Management, Vol. 17 No. 2, pp. 20-33.

Bent Flyvbjerg, "Five Misunderstandings About Case Study Research." Qualitative Inquiry, vol. 12, no. 2, April 2006, pp. 219245.

Berry, L., Lefkowith, E. and Clark, T. (1988), "In services, what's in a name", Harvard Business Review, Vol. 66, pp. 28-30

Boulding, K.E. (1956), The Image, University of Michigan Press, Ann Arbor, MI.

Burton ,D (2000), "Research Training for Social Scientists" , Sage Publications, First Edition

'Building brand values through internal marketing', Strategic Direction VOL. 23 NO. 6 2007, pp. 8-9 Review of Papasolomou, I. and Vrontis, D. (2006), "Building corporate branding through internal marketing: the case of the UK retail banking industry", Jour- nal of Product \& Brand Management, Vol. 15 No. 1, pp. 37-47.

Christine Vallaster and Leslie de Chernatony (2006), 'Internal brand building and structuration: The role of leadership' European Journal of Marketing, Vol. 40 No. 7/8, pp. 761-784

Ciulla, J.B. (1999) The importance of leadership in shaping business values. Long Range Planning 32(2), 166-72

Dachler, H.P. (1988), "Constraints on the emergence of new vistas in leadership and management research: an epistemological overview", in Hunt, J.G., Baliga, B.R. and Dachler, H.P. (Eds), Emerging Leadership Vistas, Lexington Books, Lexington, MA, pp. 261-85

Dachler, H.P. (1992), "Management and leadership as relational phenomena", in van Cranach, M., Doise, W. and Mugny, J. (Eds), Social Representation and the Social Basis of Knowledge, Haupt, Bern, pp. 169-78.

Dachler, H.P., Pless, N. and Raeder, S. (1994), "Psychologie der Fu"hrung: Fragen und Antworten im Spannungsfeld unterschiedlicher Wertvorstellungen und Menschenbilder", Psychoscope, Vol. 15, pp. 7-10.

David A.Aaker and Alexander L. Biel (1993), "Brand Equity and Advertising-Advertising's role in Building Strong Brands", Lawrence Erlbaum Associates

David F.D'alessandro(2001), "Brand Warfare: 10 Rules for building the killer brand ", McGraw Hill

Davidson, H. (2002) The Committed Enterprise. Oxford: ButterworthHeinemann

De Chernatony, Drury and Horn (2004) 'Identifying and sustaining services brands' values' Journal of Marketing Communication, Vol 10, pp 73-93

De Chernatony, L (2006), "From Brand Vision to Brand Evaluation". Elsevier LTD

De Chernatony, L and McDonald,M (2005), “Creating powerful brands", Elsevier Butterworth-Heinemann

De Chernatony, L and Segal-Horn,S (2003), 'The criteria for successful services brands', European Journal of Marketing ,Vol. 37 No. 7/8, pp. 1095-1118

De Chernatony, L and Vallaster, C (2006)'Internal brand building and structuration: the role of leadership ' European Journal of Marketing, VOl. 40, No 7/8, pp 761-784

De Chernatony,L \& Harris, F (2001) 'Corporate branding and corporate brand performance' European journal of marketing Vol. 35 No. 3/4, 2001, pp. 441-456

Derek Torrington, Laura Hall \& Stephen Taylor (2005) "Human Resource Management" Prentice Hall, Fifth Edition

Fiona Harris and Leslie de Chernatony (2001) 'Corporate branding and corporate branding performance', European Journal of Marketing , Vol. 35 No. 3/4, pp. 441-456.

\section{Web REFERENCES}

\section{1. www.clickz.com}

2. www.colbd.com

2. http://www.asocio.org/member/BCS/Bangladesh-Profile.pdf

4. www.mindbranch.com

5. http://www.internetworldstats.com/asia.htm\#bd

6. http://www.ispa.org.bd/news.php

7. http://www.sdnbd.org/sdi/issues/IT-

computer/article/itreview-sdnp.htm 


\section{APPENDIX}

\section{Qualitative Interview questions}

1. How are the new employees introduced about the company and the brand in the firm? Which department does this job?

2. What is your impression about the communication with employees on their introduction?

3. Do they provide you any sort of training for brand delivery?

4. Do you think it is important for delivering the desired performance? Please mention about your own experience, if relevant.

5. Does the company inform the employees about external marketing communication to its employees in advance?

6. Do you think informing about external marketing activities gives better inspiration to the employees give better input and gives better brand identity to the employees about the company's brand?

7. How do you describe the external marketing communication activities of the firm? What do think about the consumers' perception about the brand of the ISPs?

8. Do you think the company's marketing communication makes any difference in your performance? Does it motivate you better?

9. Does the success of a marketing communication give positive change in your perception about the brand?
10. Which department (Marketing, HRM or senior management) do you think is important for delivering internal communication?

11. Do you think it could be handy to include any other department to be introduced for internal communication purpose or it can be done well with better co-ordination of HRM, Marketing and senior management activities?

12. How much do you think the other departments delivering according to the internal communication? If you are a front end staff please say about back end staff(in this case engineers) and if you are a back end employee please state about the front end staff.

13. Do different departments and staffs help each other to be inline with the internal communication?

14. Do the employees get rewarded for delivering service according to the set standard for delivering the brand performance? Or the regular salary is designed to deliver that service?

15. How important is the leader or chief executive officer for delivering internal communication for an ISP (Internet Service Provider)? Is he the main person responsible to deliver internal communication or the responsibility is shared by corporate management?

16. Do you term all the internal communication activities as internal branding (marketing the brand to the employees) of the company? Does it increase the brand value of the firm?

17. How the whole process of internal communication could be improved? Any suggestion?

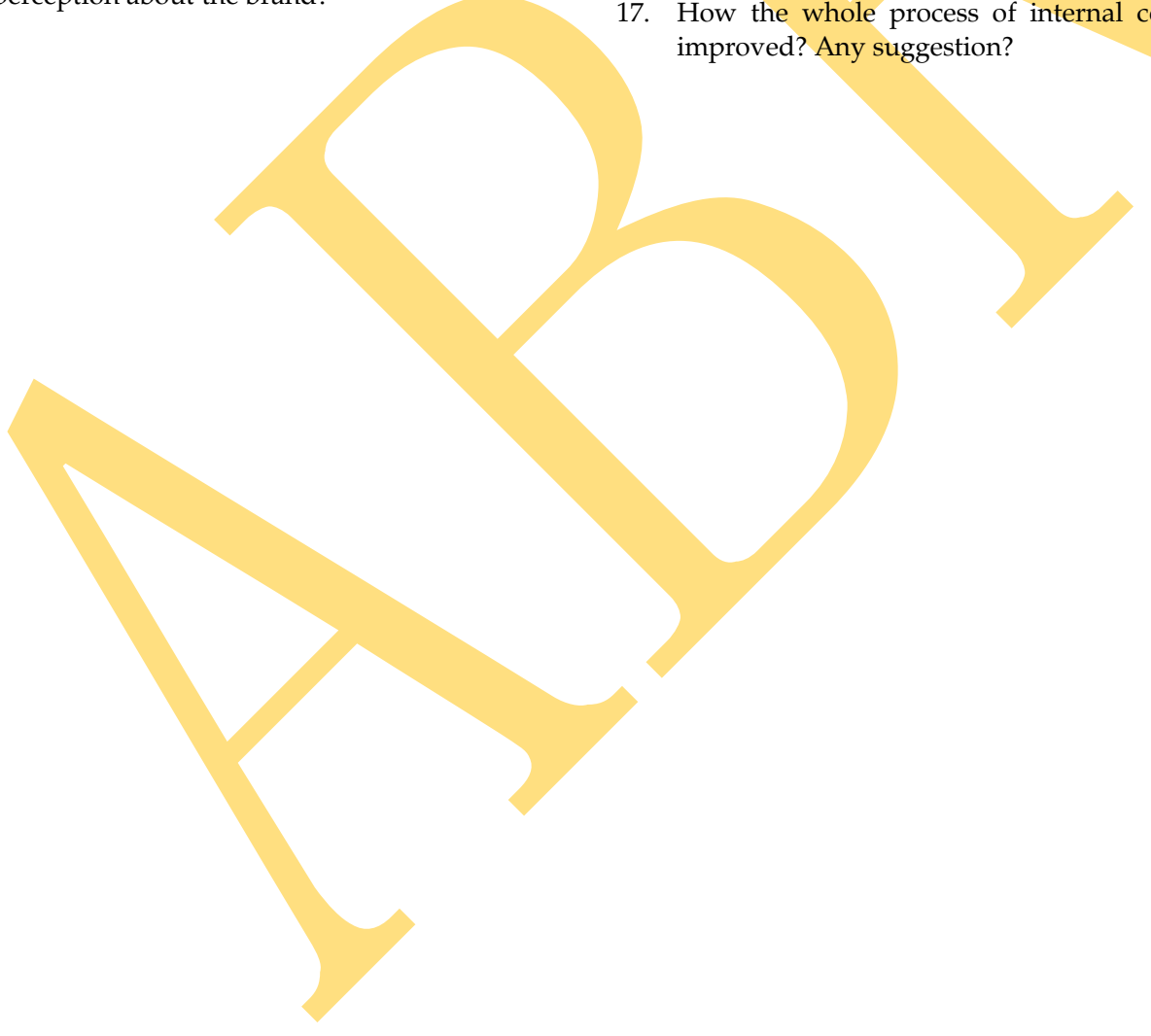

